\title{
Editorial
}

\section{Publisher's Note: Clinical and Translational Neuroscience- A Swiss Journal for a Global Readership}

\section{Peter Roth}

check for updates

Citation: Roth, P. Publisher's Note: Clinical and Translational

Neuroscience-A Swiss Journal for a Global Readership. Clin. Transl.

Neurosci. 2021, 5, 12. https:// doi.org/10.3390/ctn5020012

Received: 9 July 2021

Accepted: 9 July 2021

Published: 15 July 2021

Publisher's Note: MDPI stays neutral with regard to jurisdictional claims in published maps and institutional affiliations.

Copyright: (C) 2021 by the author. Licensee MDPI, Basel, Switzerland. This article is an open access article distributed under the terms and conditions of the Creative Commons Attribution (CC BY) license (https:// creativecommons.org/licenses/by/ $4.0 /)$.
MDPI, St. Alban-Anlage 66, CH-4052 Basel, Switzerland; roth@mdpi.com

In its 5th year of existence, the journal CLINICAL AND TRANSLATIONAL NEUROSCIENCE [1] was transferred to the MDPI journal portfolio. It's affiliated with 5 neurological societies represented by the Swiss Federation of Clinical Neuro-Societies (SFCNS) [2]. Currently the Editorial Board consists of 38 experts together with 7 Editors who monitor and manage not only the contents but also the different editorial publishing processes to guarantee fair and efficient results [3]. The journal follows an author-centered philosophy to ensure that findings can be shared quickly with other researchers around the world to stimulate fruitful research activities without delay.

The journal offers a wide variety of sections which should ease the start of community building Special Issues [4]. Please submit your ideas and proposals through the journal website! https://www.mdpi.com/journal/ctn/special_issues.

And if you are confronted with difficulties to organize the necessary funding for the article processing fees-please don't hesitate to ask the Editorial Office for discounts or waivers.

A warm welcome with a toast to the entire Editorial Board, active reviewers, authors, readers and society members for the relaunch of CLINICAL AND TRANSLATIONAL NEUROSCIENCE!

Conflicts of Interest: The author holds the position as a Publisher at MDPI.

\section{References}

1. Clinical and Translational Neuroscience Homepage. Available online: https://www.mdpi. com/journal/ctn (accessed on 9 July 2021).

2. Swiss Federation of Clinical Neuro-Societies Homepage. Available online: https://www.sfens. ch (accessed on 9 July 2021).

3. Clinical and Translational Neuroscience Editorial Board. Available online: https://www.mdpi. $\mathrm{com} /$ journal/ctn/editors (accessed on 9 July 2021).

4. Clinical and Translational Neuroscience Special Issues. Available online: https://www.mdpi. com/journal/ctn/special_issues (accessed on 9 July 2021). 